\title{
KONSEP DAN PERHITUNGAN BAGI HASIL PADA PENGHIMPUNAN DANA (FUNDING) DI BANK SYARIAH
}

\author{
Rudi Hartono \\ IAIN Syaikh Abdurrahman Siddik Bangka Belitung \\ Email: rudihartono8868@gmail.com
}

\begin{abstract}
Sharia bank fund raising products are known as deposits, which generally consist of demand deposits for wadiah, mudharabah savings deposits, and deposits. The operational principle in Islamic banks that are applied in collecting public funds is the principle of wadi'ah and mudharabah. In the case of the authority of the mudharabah law is divided into two, namely mudharabah mutlaqoh and mudharabah muqoyyadah. The steps taken in calculating the profit sharing of funds in Islamic banks include using the revenue sharing method, separating funds originating from mudharabah investment, calculating all total funds, calculating the average financing, summing total income, subtracting the percentage of investment, and determining the amount of profit obtained. The method used in deriving revenue sharing for depositors in Islamic banks is to use the calculation of investment returns per thousand and use profitsharing calculations based on the average daily balance of all deposits and similar distribution income.
\end{abstract}

Keywords: Profit Sharing, Funding, Islamic Banking 
Abstrak

Pada produk penghimpunan dana bank syariah dikenal dengan istilah simpanan yang pada umumnya terdiri dari produk giro wadiah, tabungan dan deposito mudharabah. Prinsip operasional di bank syariah yang diterapkan dalam penghimpunan dana masyarakat adalah prinsip wadi'ah dan mudharabah. Dalam hal kewenangan prinsip mudharabah terbagi dua yaitu mudharabah mutlaqoh dan mudharabah muqoyyadah. Tahapan yang dilakukan dalam menghitung bagi hasil penghimpunan dana di bank syariah antara lain menggunakan metode revenue sharing, memisahkan dana yang bersumber investasi mudharabah, menghitung seluruh total dana, menghitung rata-rata pembiayaan, menjumlahkan total pendapatan, mengurangkan persentase investasi, dan menetapkan besarnya pendapatan yang diperoleh. Metode yang dipakai dalam menghitung bagi hasil untuk penyimpan dana di bank syariah yaitu menggunakan perhitungan hasil investasi per seribu dan menggunakan perhitungan bagi hasil berdasarkan saldo rata-rata harian seluruh simpanan dan pendapatan distribusi sejenis.

Kata Kunci: Bagi Hasil, Funding, Bank Syariah

\section{A. Pendahuluan}

Lembaga Keuangan Bank adalah badan usaha yang melakukan kegiatan dibidang keuangan dengan menghimpun dana dari masyarakat dalam bentuk simpanan dan menyalurkannya kembali dalam bentuk pembiayaan. ${ }^{1}$ Dalam pasal 1 ayat 2 undang-undang Republik Indonesia nomor 10 tahun 1998 tentang perbankan, definisi bank adalah sebuah badan usaha yang menghimpun dana dari masyarakat dalam bentuk simpanan dan menyalurkannya kepada masyarakat dalam bentuk kredit dan atau bentuk-

${ }^{1}$ Ansori, Abdul Ghofur, Penerapan Prinsip Syariah Dalam Lembaga Keuangan Lembaga Keuangan dan Perusahaan Pembiayaan. (Yogyakarta: Pustaka Pelajar, 2008), hlm. 15. 
bentuk lainnya dengan tujuan untuk meningkatkan taraf hidup orang banyak. Dalam kegiatan usahanya, bank melaksanakannya dengan cara konvesional dan berdasarkan prinsip syariah.

Bank syariah adalah bank yang dalam menjalankan usahanya berdasarkan pada prinsip-prinsip syariah Islam $^{2}$ yang secara operasional berbeda dengan bank konvensional. ${ }^{3}$ Bank syariah terdiri dari dua macam, yaitu Bank Umum Syariah dan Bank Pembiayaan Rakyat Syariah. Bank Umum Syariah ialah bank yang dapat memberikan jasa dalam lalu lintas pembayaran yang sesuai dengan syariah Islam. ${ }^{4}$ Sedangkan Bank Perkreditan Rakyat adalah bank yang berdasarkan Prinsip Syariah ${ }^{5}$, dalam kegiatannya tidak memberikan jasa dalam lalu lintas pembayaran. ${ }^{6}$ Dua fungsi pokok bank yaitu penghimpunan dana masyarakat dan penyaluran dana kepada masyarakat, oleh karena itu disebut Financial Intermediary. ${ }^{7}$

Secara kelembagaan bank umum syariah ada yang berbentuk bank syariah penuh dan ada yang berbentuk unit usaha syariah (UUS) dari bank umum konvensional.

Kegiatan Bank Umum Syariah secara garis besar dapat dibagi menjadi tiga fungsi utama yaitu; penghimpunan dana pihak ketiga atau dana masyarakat, penyaluran dana kepada pihak yang membutuhkan, dan

${ }^{2}$ M.Sulhan \& Ely Siswanto, Manajemen Bank:Konvensional dan Syariah. (Malang: UINMalang Press,2008), hlm. 125

${ }^{3}$ Ismail, Perbankan Syariah. (Jakarta: Kencana Prenada Media Group, 2011), hlm. 29

${ }^{4}$ Habib Nazhir dan Muhammad Hasanuddin, Ensiklopedi Ekonomi dan Perbankan Syariah (Bandung: Kafa Publishing, 2008), hlm. 83

${ }^{5}$ Prinsip syariah adalah aturan perjanjian berdasarkan hukum Islam antara Bank dan pihak lain untuk penyimpanan dana atau pembiayaan kegiatan usaha atau kegiatan lainnya yang dinyatakan sesuai dengan syariah. (https://accounting.binus.ac.id > 2017/06/17). Lihat juga di https://www.syariahbukopin.co.id/id/syariah dijelaskan prinsip syariah adalah prinsip hukum Islam dalam kegiatan perbankan (penyimpanan dana dan/atau kegiatan lainnya) berdasarkan fatwa yang dikeluarkan oleh lembaga Dewan Syariah Nasional (DSN) yang memiliki kewenangan dalam penetapan fatwa di bidang syariah, akses tanggal 21 Juni 2019 jam 14:00

${ }^{6}$ Wiroso, Penghimpunan Dana dan Distribusi Hasil Usaha Bank Syariah. (Grasindo, Jakarta: 2005), hlm. 2

7 Ismail, Perbankan......, hlm. 30-31 
pelayanan jasa bank. ${ }^{8}$ Hingga periode april 2019, jumlah Bank Umum Syariah di Indonesia ada 14 kantor. ${ }^{9}$

Bank syariah mempunyai peran penting untuk mengelola dana yang telah dihimpun dari pemilik dana (shahibul maal), sehingga pendapatan yang dihasilkan oleh bank syariah dalam mengelola dana mudharabah sangat tergantung pada keahlian, kehati-hatian, dan profesionalitas dari bank syariah. ${ }^{10}$

Bagi hasil dalam penghimpunan dana (funding) yang diberikan kepada pemilik dana (shahibul maal) sangat berpengaruh terhadap pendapatan yang dihasilkan oleh bank syariah dalam mengelola dana dengan akad bagi hasil (mudharabah). ${ }^{11}$

Dalam penentuan besarnya bagi hasil yang akan dibagikan kepada pemilik dana, terdapat perbedaan pada metode perhitungan bagi hasil yang digunakan oleh bank-bank syariah. Perbedaan tersebut sangat mempengaruhi bagi hasil yang akan diterima para pemilik dana (shahibul maal) yang menempatkan dananya dengan akad mudharabah. Untuk itu, perlu dipahami bagaimana konsep dan tahapan dalam menghitung bagi hasil penghimpunan dana (funding) di bank syariah.

\section{B. Produk penghimpunan dana bank syariah}

Pada produk penghimpunan dana bank syariah dikenal dengan istilah simpanan. Simpanan adalah dana yang dipercayakan oleh masyarakat kepada bank dalam bentuk simpanan giro, deposito, tabungan atau bentuk lainnya yang dipersamakan.

${ }^{8}$ Ibid, hlm.52

9 Otoritas Jasa Keuangan (OJK), Statistik Perbankan Syariah, april 2019 (https://ojk.go.id/id/kanal/syariah/data-dan-statistik/statistik-perbankansyariah/Documents/Pages/Statistik-Perbankan-Syariah---April2019/SPS\%20April\%202019.pdf), akses tanggal 25 Juni 2019 jam 16:45

10 Wiroso, Penghimpunan Dana...., hlm. 5

11 Ibid, hlm. 7 
Bentuk-bentuk simpanan yang disebutkan dalam UU No. 10 tahun 1998 adalah:

a. Giro, yaitu simpanan yang dapat digunakan sebagai alat pembayaran dan penarikannya dapat dilakukan kapan saja dengan menggunakan cek, bilyet giro, sarana perintah pembayaran lainnya atau dengan pemindahbukuan.

b. Deposito, yaitu simpanan yang penarikannya dapat dilakukan hanya pada waktu tertentu berdasarkan perjanjian antara nasabah dengan bank

c. Serifikat deposito adalah simpanan deposito berjangka yang sertifikat sebagai bukti penyimpanan dapat diperjualbelikan.

d. Tabungan, yaitu simpanan yang penarikannya dapat dilakukan kapan saja berdasarkan syarat tertentu yang telah disepakati, tetapi tidak dapat ditarik menggunakan cek, bilyet giro atau alat lainnya yang dapat dipersamakan dengan itu. ${ }^{12}$

\section{Prinsip-prinsip dalam penghimpunan dana bank syariah}

Dalam penghimpunan dana bank syariah terdapat dua prinsip, yaitu prinsip wadi'ah dan prinsip mudharabah.

a. Prinsip wadi'ah

Dalam prinsip wadi'ah (simpanan murni), pihak pemilik dana (shahibul maal) dalam hal ini deposan atau penyimpan menitipkan dananya kepada pihak pengelola (mudharib) dalam hal ini bank syariah untuk dimanfaatkan atau tidak dimanfaatkan sesuai ketentuan. Titipan ini dapat dilakukan kapanpun saat dibutuhkan oleh pihak penitip. ${ }^{13}$

Prinsip wadi'ah yang diterapkan di perbankan syariah Indonesia yaitu wadi'ah yad al-amanah adalah akad titipan suatu barang/uang dari suatu pihak ke pihak lainnya dimana pihak yang menerima titipan tidak diperkenankan menggunakan barang yang dititipkan seperti Safe Deposit Box (SDB) yang ada di bank syariah, dan wadi'ah yad dhamanah adalah akad titipan suatu barang/uang dari suatu pihak ke pihak lainnya dimana pihak

\footnotetext{
12 Anshori, H.Abdul Ghofur, Tanya Jawab Perbankan Syariah. (Yogyakarta: UII Press, 2008), hlm. 43-44

13 Ismail, Perbankan....hlm. 59
} 
yang menerima titipan diperbolehkan memanfaatkan barang yang dititip seperti simpanan giro ataupun tabungan yang ada di bank syariah. ${ }^{14}$

b. Prinsip mudharabah

Mudharabah adalah kontrak antara dua pihak dimana satu pihak yang disebut rab al-mal (investor) mempercayakan uang kepada pihak lainnya yang disebut mudharib untuk tujuan menjalankan usaha. Salah satu ciri utama dari konrtrak ini adalah bahwa, jika ada, akan dibagi antara investor dan mudharib berdasarkan proporsi yang telah disepakati sebelumnya. ${ }^{15}$ Dalam aplikasi prinsip mudharabah yaitu deposan atau penyimpan dalam hal ini nasabah bertindak sebagai pemilik dana (shahibul maal) dan bank bertindak sebagai pengelola (mudharib) ${ }^{16}$, sehingga dalam hal bank syariah melakukan perhitungan distribusi hasil usaha sangat terkait erat dengan dana yang dihimpun, khususnya dana yang dihimpun dengan prinsip mudharabah. ${ }^{17}$

Dalam hal kewenangan yang diberikan oleh pihak deposan atau pemilik dana yang menginvestasikan dananya di bank syariah, prinsip mudharabah terbagi dua yaitu:

\section{Mudharabah Mutlaqoh}

Mudharabah mutlaqoh merupakan akad perjanjian antara dua pihak yaitu shahibul maal dan mudharib, yang mana shahibul maal menyerahkan sepenuhnya atas dana yang diinvestasikan kepada mudharib untuk mengelola usaha hanya sesuai dengan prinsp syariah. Shahibul maal tidak memberikan batasan jenis usaha, waktu yang diperlukan, strategi pemasarannya, serta wilayah bisnis yang dilakukan. Shahibul maal memberikan kewenangan yang sangat besar kepada mudharib untuk

${ }^{14}$ Anshori, H.Abdul Ghofur, Tanya Jawab.....hlm. 45

${ }^{15}$ Saeed, Abdulah. Menyoal Bank Syariah: Kritik atas Interpretasi Bunga Bank Kaum NeoRevivalis. (Jakarta: Paramadina, 2004), hlm. 77

16 Ibid, hlm. 46

17 Wiroso, Penghimpunan Dana...., hlm. 19 
menjalankan aktivitas usahanya, asalkan sesuai dengan prinsip syariah Islam. Jenis investasi mudharabah mutlaqoh dalam aplikasi perbankan syariah dipakai dalam produk tabungan dan deposito ${ }^{18}$, sehingga dalam penghimpunan dana disebut tabungan mudharabah dan deposito mudharabah. ${ }^{19}$

2. Mudharabah Muqoyyadah

Mudharabah Muqoyyadah merupakan akad perjanjian antara dua pihak yaitu shahibul maal dan mudharib, yang mana shahibul maal menginvestasikan dananya kepada mudharib, dan memberikan batasan atas penggunaan dana yang diinvestasikannya. Batasannya antara lain:

a. Tempat dan cara berinvetasi

b. Jenis Investasi

c. Objek investasi

d. Jangka waktu. ${ }^{20}$

Mudahrabah muqoyyadah terbagi menjadi dua jenis, yaitu mudharabah muqoyyadah on Balance Sheet dan mudharabah muqoyyadah of Balance Sheet.

a. Mudharabah muqoyyadah on Balance Sheet

Mudharabah muqoyyadah on Balance Sheet merupakan akad yang mana mudharib ikut menanggung risiko atas kerugian yang diinvestasikan oleh shahibul maal. Dalam akad ini, shahibul maal memberikan batasan secara umum, misalnya batasan mengenai jenis usaha, jangka waktu pembiayaannya, dan sektor usahanya.

Misalnya, nasabah menempatkan dananya dalam deposito dengan akad mudharabah muqoyadah on balance sheet sebesar Rp. 500.000.000,- untuk proyek pembangunan jalan tol, dalam jangka waktu 5 tahun. Maka dalam akad ini, nasabah memberikan batasan terkait proyek usaha dan jangka

18 Ismail, Perbankan...., hlm. 86-87

1919 Adiwarman A. Karim, Bank Islam: Analisis Fiqih dan Keuangan (Jakarta: PT Raja Grafindo Persada, 2004), hlm. 109

20 Ismail, Perbankan...., hlm. 87 
waktunya. Bank syariah akan melakukan investasi khusus untuk proyek jalan tol dan jangka waktu yang tidak boleh dari 5 tahun sebesar Rp. 500.000.000,-. Bagi hasil yang didapatkan oleh mudharib (bank syariah) akan diterima shahibul maal (nasabah) sesuai kesepakatan. Bagi hasil ini harus dipisahkan dari bagi hasil atas akad mudharabah mutlaqoh. ${ }^{21}$

Karakteristik dari simpanan dengan akad mudharabah muqoyadah on balance sheet, yaitu:

- Shahibul maal (pemilik dana) dalam hal ini nasabah, menetapkan syaratsyarat kepada mudharib (pengelola) dalam hal ini bank syariah terkait jenis usaha, jangka waktu yang ada dalam akad dana simpanan khusus.

- Bank syariah menjelaskan kepada nasabah terkait nisbah dan mekanisme pembagian keuntungan serta risiko yang dapat ditimbulkan dari penyimpanan dana yang tercantum dalam akad.

- Selanjutnya bank syariah menerbitkan bukti simpanan khusus sebagai tanda bukti simpanan dan memisahkan dana dari rekening lainnya

b. Mudharabah muqoyyadah off Balance Sheet

Mudharabah muqoyyadah off Balance Sheet merupakan akad yang mana mudharib telah ditetapkan oleh shahibul maal. Shahibul maal memberikan batasan terkait proyek yang diperbolehkan, jangka waktu dan pihak pelaksana pekerjaan. Dalam pelaksanaannya, bank syariah mendapatkan fee yang bertindak sebagai pihak yang mempertemukan (agen) antara shahibul maal dan mudharib. Laporan keuangan dicatat dalam catatan atas laporan keuangan.

Karakteristik dari simpanan dengan akad mudharabah muqoyadah off balance sheet, yaitu: 
- Bank syariah harus memisahkan dana dari rekening lainnya

- Sebagai bukti simpanan, bank syariah menerbitkan bukti simpanan khusus yang tercatat dalam rekening administratif.

- Shahibul maal dan mudharib menetapkan nisbah bagi hasil dari keuntungan yang akan didapatkan

- Selanjutnya bank syariah menyalurkan langsung kepada pihak yang diamanatkan oleh shahibul maal (pemilik dana).

- Bank syariah mendapatkan komisi dari mempertemukan kedua belah pihak $^{22}$

\section{Sistem bagi hasil dan penentuan nisbah bagi hasil}

1. Sistem bagi hasil

Ada beberapa langkah dalam penentuan sistem bagi hasil di bank syariah, yaitu:

a. Besarnya bagi hasil yang didapatkan berpedoman pada kemungkinan untung rugi yang telah disepakati dalam akad.

b. Adanya kerelaan dari kedua belah pihak terkait besarnya porsi bagi hasil yang didapatkan tanpa ada unsur paksaan.

c. Bagi hasil yang diterima tergantung dari keuntungan usaha yang dijalankan

d. Besarnya pembagian bagi hasil sesuai dengan jumlah pendapatan yang diperoleh. ${ }^{23}$

2. Nisbah bagi hasil

Nisbah adalah perbandingan berupa persentase yang disepakati di awal akad berkaitan dengan pembagian keuntungan dari kegiatan usaha. ${ }^{24}$

22 Adiwarman A. Karim, Bank Islam:..........., hlm. 110-111 hlm. 99

23 Muhamad, Sistem Bagi Hasil dan Pricing Bank Syariah, (Yogyakarta: UII Press, 2016),

${ }^{24}$ Anshori, H.Abdul Ghofur, Tanya Jawab.....hlm. 50 
Nisbah bagi hasil merupakan persentase keuntungan antara shahibul maal (pemilik dana) dengan mudharib (pengelola) yang telah ditentukan dengan kesepakatan kedua belah pihak. Jika usaha yang dijalankan mengalami kerugian, maka pembagian kerugian didasarkan atas porsi modal yang disetor oleh masing-masing pihak.

Dalam akad mudharabah, 100\% modal berasal dari shahibul maal. Jika terjadi kerugian, maka kerugian usaha akan ditanggung sepenuhnya oleh shahibul maal. Oleh karena itu, nisbah bagi hasil disebut juga dengan nisbah keuntungan. ${ }^{25}$

3. Karakteristik nisbah bagi hasil

Ada beberapa karakteristik dalam nisbah bagi hasil, yaitu:

a. Persentase

Nisbah bagi hasil dinyatakan dalam persentase (\%), bukan dalam nominal uang

b. Pembagian keuntungan

Pembagian keuntungan didasarkan atas nisbah yang telah disepakati, sedangkan jika terjadi kerugian didasarkan atas porsi modal masingmasing pihak

c. Besaran nisbah

Besarnya nisbah yang ditetapkan sesuai dengan hasil tawar-menawar yang dilandasi kesepakaan kedua belah pihak antara shahibul maal (pemilik dana) dengan mudharib (pengelola)

d. Penyelesaian kerugian

Jika terjadi kerugian, maka akan ditanggung dari keuntungan terlebih dahulu. Ketika kerugian melebihi keuntungan, maka akan diambil dari modal pokok.

4. Cara menetapkan nisbah bagi hasil funding (pengumpulan dana)

${ }^{25}$ Muhamad, Sistem Bagi Hasil......., hlm. 101 
Nasabah yang menempatkan dananya di bank syariah dengan akad mudharabah, akan mendapatkan bagi hasil yang didasarkan pada nisbah bagi hasil yang ditetapkan oleh bank. Adapun cara menetapkan nisbah bagi hasil pada produk penghimpunan dana adalah sebagai berikut:

a. Hitung pendapatan bank, misalnya sebesar $15 \%$ p.a (per annual)

b. Hitung biaya-biaya misalnya sebesar $4 \%$ dan penghapusan penyisihan aktiva produktif (PPAP) sebesar 1\% per annual.

c. Tentukan harapan keuntungan, misalnya $4 \%$

d. Hitung nisbah untuk bank (biaya + harapan keuntungan)/pendap tan $=$ $(5 \%+3 \%) / 15,32 \%=52,2 \%$.

Nisbah maksimal untuk nasabah $=100 \%$-nisbah bank $=100-52,2 \%=$ $47,8 \%$.

Besaran nisbah yang digunakan adalah berdasarkan kesepakatan masing-masing pihak yang berkontrak pada akad mudharabah muqoyyadah. Sedangkan dalam akad mudharabah mutlaqoh ditentukan oleh pihak bank syariah yang sudah tersistem dalam komputerisasi. Angka nisbah pun bervariasi sesuai kebijakan bank, misalnya 50:50, 60:40, 70:30, 80:20, bahkan 99:1, untuk bank dengan nasabah atau sebaliknya.

Dalam praktiknya di bank syariah, tawar-menawar nisbah antara pemilik dana (nasabah) dengan pihak pengelola (bank syariah) terjadi pada deposan/investor yang menempatkan dana dalam jumlah yang besar, karena memiliki daya tawar yang relatif tinggi. Kondisi ini disebut dengan special nisbah.

Sedangkan untuk nasabah yang menempatkan dananya tidak terlalu besar, biasanya tawar-menawar tidak terjadi. Bank syariah menetapkan nisbah sesuai nisbah counter yang sudah ditentukan. ${ }^{26}$

${ }^{26}$ Ibid, hlm. 103-105 
Nisbah counter yang tertulis di papan informasi bank syariah, contohnya sebagai berikut:

\begin{tabular}{lll}
\hline Nama produk & \multicolumn{2}{c}{ Nisbah } \\
\cline { 2 - 3 } & Nasabah & Bank \\
\hline a. Tabungan A & $10 \%$ & $90 \%$ \\
Tabungan B & 30 & 70 \\
b.Deposito & & \\
- Jangka waktu 1 bulan & $50 \%$ & $50 \%$ \\
- Jangka waktu 3 bulan & $51 \%$ & $49 \%$ \\
- Jangka waktu 6 bulan & $53 \%$ & $47 \%$ \\
- Jangka waktu 12 bulan & $54 \%$ & $46 \%$
\end{tabular}

\section{E. Faktor yang mempengaruhi bagi hasil}

Ada beberapa faktor yang mempengaruhi bagi hasil yang akan didapatkan, yaitu:

1. Persentase dana yang akan diinvestasikan kembali oleh bank syariah ke dalam pembiayaan.

2. Total dana yang diterima dari berbagai sumber dan yang tersedia untuk diinvestasikan.

3. Nisbah bagi hasil yang telah disepakati antara bank dan nasabah investor

4. Metode penentuan bagi hasil yang digunakan, yaitu bagi hasil yang menggunakan revenue sharing dan profit/loss sharing. Bagi hasil yang menggunakan revenue sharing, dihitung dari pendapatan kotor sebelum dikurangi dengan biaya sedangkan bagi hasil dengan profit/loss sharing dihitung berdasarkan persentase nisbah dikalikan dengan laba usaha sebelum pajak.

5. Kebijakan akuntansi yang diterapkan oleh bank syariah antara lain penyusutan. Bila menerapkan metode profit/loss sharing, maka 
penyusutan akan mempengaruhi bagi hasil, akan tetapi bila menggunakan revenue sharing tidak mempengaruhi bagi hasil. ${ }^{27}$

\section{F. Mekanisme Perhitungan Bagi Hasil}

Ada tiga mekanisme yang dikenal dalam perhitungan bagi hasil pada bank syariah, yakni:

a. Profit Sharing mechanism, yaitu perhitungan bagi hasil dengan menggunakan metode bagi untung (profit).

Profit $=$ Revenue $($ tax + fix cost + variable cost $)$. Jadi yang dibagi adalah keuntungan bersih (net profit).

Dalam hal rugi, maka pembagiannya: secara finansial dianggung oeh pemilik dana (shahibul maal), sedangkan pengelola menanggung resiko tidak mendapatkan apa-apa, kecuali jika pengelola karena kesalahnnya juga menyebabkan terjadinya rugi.

Metode ini dipakai, khususnya dalam produk pembiayaan berdasarkan prinsip mudharabah.

b. Profit and loss sharing mechanism, yaitu perhitungan bagi hasil dimana keuntungan bersih (net profit) dibagi sesuai dengan nisbah yang disepakati diawal, sedangkan dalam ha kerugian (loss) kedua pihak ikut menanggung kerugian secara finansial sesuai dengan penyertaan modalnya masing-masing.

Metode ini dipakai, khususnya dalam produk pembiayaan berdasarkan akad musyarokah.

c. Revenue Sharing mechanism, yaitu perhitungan bagi hasil dimana yang dibagi bukan keuntungan bersih, akan tetapi pendapatan (revenue). Jadi belum ada pengurangan biaya-biaya.

${ }^{27}$ Ismail, Perbankan...., hlm. 96-98 
Metode ini dipakai, khususnya dalam simpanan mudharabah dan pembiayaan mudharabah. ${ }^{28}$

Pada umumnya bagi hasil terhadap investasi dana dari masyarakat menggunakan revenue sharing.

Ada beberapa alasan kenapa tidak memakai perhitungan secara profit sharing oleh Bank Syariah.

a. Bila dihitung berdasarkan pendapatan bersih maka kemungkinan bagi hasil yang diterima pemilik dana (shahibul maal) akan semakin kecil dan ini akan berdampak, apabila suku bunga pasar lebih tinggi, pada turunnya minat masyarakat untuk menyimpan uang di Bank Syariah.

b. Bila Bank Syariah memakai mekanisme profit sharing, maka bank harus menyisihkan sebagian keuntungannya untuk mensubsidi pendapatan bagi hasi yang akan diperoleh nasabah. Ini berarti bank akan memperoleh keuntungan yang lebih kecil.

c. Kondisi para pelaku usaha Indonesia yang sampai saat ini, belum sepenuhnya berlaku jujur dan masih banyak praktek "moral hazard", sehingga tidak memungkinkan bank menggunakan mekanisme perhitungan bagi hasi secara profit sharing. ${ }^{29}$

\section{G. Tahap perhitungan bagi hasil dana pihak ketiga}

Dana Pihak Ketiga (DPK) adalah dana yang berasal dari masyarakat berupa tabungan, giro dan deposito.

Dalam produk penghimpunan dana (funding), bank syariah umumnya menggunakan produk giro wadiah, tabungan dan deposito mudharabah. ${ }^{30}$

${ }^{28}$ Anshori, H.Abdul Ghofur, Tanya Jawab....., hlm. 49-50

${ }^{29}$ Yunaldi, Wendra, Potret Perbankan Syariah di Indonesia, Jakarta Centralis, 2007, hlm. 105-106.

30 Ari Kristin Prasetyoningrum, Risiko Bank Syariah, Yogyakarta: Pustaka Pelajar Bekerjasama dengan LP2M UIN Walisongo, 2015, hlm. 93-94. 
Ada beberapa tahapan yang dilakukan dalam menghitung bagi hasil penghimpunan dana di bank syariah antara lain:

1. Menggunakan metode revenue sharing, yaitu dengan menghitung total pendapatan tanpa ada pengurangan biaya-biaya.

2. Memisahkan dana yang bersumber investasi mudharabah dengan dana selain investasi mudharabah.

3. Menghitung seluruh total dana yang bersumber dari investasi mudharabah mutlaqoh.

4. Menghitung rata-rata pembiayaan dari total keseluruhan akad pembiayaan, baik akad jual beli, kerjasama usaha dan sewa pada bulan laporan.

5. Menjumlahkan total pendapatan yang didapatkan dari margin keuntungan, pendapatan bagi hasil dan pendapatan sewa.

6. Mengurangkan persentase investasi dari total investasi mudharabah yang dijadikan sebagai cadangan giro wajib minimum sesuai ketentuan Bank Indonesia

7. Menetapkan besarnya pendapatan yang diperoleh untuk dibagi hasil antara pemilik dana (nasabah) dengan pengelola (bank syariah).

\section{H. Perhitungan bagi hasil dalam penghimpunan dana (funding)}

Ada beberapa metode/cara yang dipakai dalam menghitung bagi hasil untuk penyimpan dana di bank syariah, yaitu:

1. Menghitung saldo rata-rata harian nasabah

Saldo rata-rata harian dihitung bagi setiap jenis simpanan (giro dan tabungan). Langkah-langkah digunakan adalah sebagai berikut:

1. Menentukan tanggal berapa keuntungan yang diperoleh dari penempatan dana akan dibagi hasilkan.

2. Jumlah hari yang dihitung dalam satu bulan adalah sesuai hitungan kalender. 
Berikut contoh perhitungan saldo rata-rata harian:

\begin{tabular}{|l|l|l|r|l|}
\hline Tanggal & Sandi & Debit Rp. & Kredit Rp. & Saldo \\
\hline $1 / 10 / 2018$ & 1 & & 575.000 & 575.000 \\
\hline $3 / 10 / 2018$ & 2 & 125.000 & & 450.000 \\
\hline $10 / 10 / 2018$ & 1 & & 250.000 & 700.000 \\
\hline $15 / 10 / 2018$ & 2 & 100.000 & & 600.000 \\
\hline $21 / 10 / 2018$ & 1 & & 400.000 & 1.000 .000 \\
\hline
\end{tabular}

Dari buku tabungan ini kemudian dihitung saldo rata-rata harian per bulan, sebagai berikut:

Tgl 01/10/2019 s.d Tgl 01/10/2019= 1 hari $\times 575.000=575.000$

Tgl 02/10/2019 s.d Tgl 09/10/2019= 8 hari $\times 450.000=1.000 .000$

$\operatorname{Tgl} 10 / 10 / 2019$ s.d Tgl 14/10/2019= 4 hari $\times 700.000=2.800 .000$

$\operatorname{Tgl} 15 / 10 / 2019$ s.d Tgl 20/10/2019 = 5 hari $\times 600.000=3.000 .000$

Tgl 21/10/2019 s.d Tgl 31/10/2019= 11 hari $\times 400.000=4.400 .000$

Jumlah 31 hari $\quad=11.775 .000$,-

Sehingga saldo rata-rata harian $=11.775 .000,-: 31=379.839,-$

2. Menggunakan perhitungan hasil investasi per seribu (Hi per mil)

Bagi hasil $=\frac{\text { SRR }}{1000} \times \frac{\mathrm{N}}{100} \times \mathrm{Hi}-1000$

Dimana :

SRR : Saldo rata-rata ${ }^{31}$

N : Nisbah

Hi-1000 : hasil investasi dari setiap seribu rupiah ${ }^{32}$ yang dihasilkan ${ }^{33}$

${ }^{31}$ Saldo rata-rata dihitung untuk rekening giro dan tabungan mudharabah dalam 1 bulan

32 Besar Hi-1000 setiap bulannya akan berubah-ubah tergantung dari pendapatan bank. Nilai Hi-1000 terbaru berubah di setiap awal bulan.

${ }^{33}$ Wiroso, Penghimpunan Dana...., hlm. 165-166 
Contoh perhitungan:

Jika si Fulan membuka deposito 1 bulan sebesar Rp.10.000.000 pada bulan Mei, dengan besar nisbah 50\%. Hi-1000 pada bulan Mei 7.87, maka besar bagi hasil yang akan diterima adalah sebesar?

$$
\begin{aligned}
\text { Bagi Hasil }= & \frac{10.000 .000}{1000} \times 7.87 \times 50 \% \\
& =\text { Rp. } 39.350(\text { potong pajak } 20 \%)^{34} \\
& =\text { Rp. } 31.480 \text { (Bagi Hasil Nett yang diterima) }
\end{aligned}
$$

3. Menggunakan perhitungan bagi hasil berdasarkan saldo rata-rata harian seluruh simpanan dan pendapatan distribusi sejenis ${ }^{35}$

Perhitungan berdasarkan saldo rata-rata harian seluruh simpanan dan pendapatan disrtibusi sejenis dihitung ditiap akhir bulan dan di buku awal bulan berikutnya. Rumus yang digunakan:

$\frac{\text { Saldo rata-rata simpanan nasabah }{ }^{36}}{\text { Saldo rata-rata seluruh }} \times$ total pendapatan distribusi bagi hasil simpanan sejenis

untuk simpanan sejenis $\mathrm{x}$ nisbah bagi hasil

Contoh perhitungan:

Pak Sarman saldo rata-rata tabungan bulan agustus $2013 \mathrm{Rp} 1.000 .000,-$, perbandingan bagi hasil (nisbah) antara Bank dan Nasabah 85:15, saldo rata-rata tabungan seluruh nasabah pada agustus 2013 Rp. 2.000.000.000,-, pendapatan bank yang dibagihasilkan untuk nasabah tabungan Rp. 200.000.000,-. Berapakah jumlah bagi hasil yang diterima?

$\frac{R p \cdot 1 \cdot 000.000,-}{R p .2 .000 .000 .000} \times$ Rp. 2.00.000.000,- x 15 \% = Rp. 15.000,-

34 Peraturan Pemerintah RI Nomor 131 tahun 2000 tentang Pajak Penghasilan atas bunga deposito dan deposito serta diskonto sertifikat Bank Indonesia, Pasal 2 dan 3.

${ }_{35}$ Berdasarkan hasil observasi dan data dokumen yang didapatkan dari salah satu bank umum syariah

36 Saldo rata-rata simpanan sejenis adalah saldo rata-rata harian (tabungan dan giro) dalam satu bulan, sedangkan untuk deposito menggunakan nominal deposito, untuk simpanan sejenis 
Maka, bagi hasil yang diterima Pak Sarman sebesar Rp. 15.000,;

\section{Pembayaran bagi hasil pada penghimpunan dana (funding)}

Bagi hasil yang diberikan oleh bank syariah akan dibayarkan sesuai dengan jenis investasi mudharabah. Dasar dalam menghitung bagi hasil adalah berasal dari total investasi mudharabah, rata-rata pengendapan saldo, rata- rata pembiayaan, dan pendapaan riil pada bulan laporan.

Bagi hasil pada investasi deposito mudharabah dibayarkan pada tanggal valuta, tanggal pada saat deposito ditempatkan dan dilakukan setiap bulan, meskipun jangka waku ada yang 1 bulan, 3 bulan, 6 bulan, 12 bulan, maupun bulan. Dasar perhitungannya adalah data keuangan pada bulan laporan. ${ }^{37}$

Bank Syariah menggunakan metode end of month dalam pembayaran bagi hasil pada simpanan giro/tabungan mudharabah, yaitu:

- Pembayaran bagi hasil giro/tabungan mudharabah dilakukan secara bulanan, yaitu pada tanggal tutup buku setiap bulan.

- Bagi hasil bulan pertama dihitung secara proporsional hari efektif termasuk tanggal tutup buku, tapi tidak termasuk tanggal pembukaan tabungan

- Bagi hasil bulan terakhir dihitung secara proporsional hari efektif. Tingkat bagi hasil yang dibayar adalah tingkat bagi hasil tutup buku bulan terakhir

- Jumlah hari sebulan adalah jumlah hari kalender bulan yangn berangkutan (28 hari, 29 hari, 30 hari, 31 hari)

- Bagi hasil bulanan yang diterima nasabah dapat diafiliasikan ke rekening lainnya sesuai permintaan nasabah. ${ }^{38}$

${ }^{37}$ Ismail, Perbankan...., hlm. 103-104

38 Adiwarman A. Karim, Bank Islam:..., hlm. 300-301 


\section{J. Contoh penerapan perhitungan bagi hasil funding mudharabah di bank syariah $^{39}$}

Apabila bank syariah mampu mengumpulkan dana pihak ketiga (DPK) sebanyak Rp. 90.000.000. DPK yang dapat disalurkan pada pembiayaan sebanyak Rp. 85.500.000 karena ada Giro Wadiah Minimum sebesar 5\%). Pembiayaan yang harus disalurkan kemasyarakat sebanyak Rp. 100.000.000. Dari pembiayaan Rp.100.000.000 diperoleh pendapatan dari penyaluran pembiayaan sebesar Rp. 1.500.000. Nisbah bagi hasil 65\%:35\%. Berapa pendapatan setiap Rp. 1000 dana nasabah?

\begin{tabular}{|l|l|l|}
\hline DPK & A & 90.000 .000 \\
\hline $\begin{array}{l}\text { DPK yang dapat disalurkan pada } \\
\text { pembiayaan }\end{array}$ & B & 85.500 .000 \\
\hline Pembiayaan yang disalurkan & C & 100.000 .000 \\
\hline Dana Bank & & 14.500 .000 \\
\hline Pendapatan dari peyaluran pembiayaan & D & 1.500 .000 \\
\hline Pendapatan bagi setiap Rp. 1000 DPK & E & 14,25 \\
\hline & & \\
\hline$E=\frac{B}{C} \times D \times \frac{I}{A} \times 1000$ &
\end{tabular}

${ }^{39}$ Muhamad, Sistem Bagi Hasil......., hlm. 129-130 


\begin{tabular}{|l|l|l|}
\hline Pendapatan bagi setiap Rp. 1000 DPK & E & 14,25 \\
\hline DPK yang dapat disalurkan pada pembiayaan & F & 1.000 .000 \\
\hline Saldo rata-rata harian nasabah & G & 100.000 .000 \\
\hline Nisbah nasabah & & 65 \\
\hline Bagi hasil nasabah bulan ini & H & 9265 \\
\hline $\mathrm{H}=\frac{\mathrm{B}}{1000} \times \mathrm{F} \times \frac{\mathrm{G}}{100} \leftarrow$ & \\
\hline
\end{tabular}

\section{K. Kesimpulan}

Bank syariah mempunyai peran penting untuk mengelola dana yang telah dihimpun dari pemilik dana (shahibul maal), sehingga pendapatan yang dihasilkan oleh bank syariah dalam mengelola dana mudharabah sangat tergantung pada keahlian, kehati-hatian, dan profesionalitas dari bank syariah.

Bagi hasil dalam penghimpunan dana (funding) yang diberikan kepada pemilik dana (shahibul maal) sangat berpengaruh terhadap pendapatan yang dihasilkan oleh bank syariah dalam mengelola dana dengan akad bagi hasil (mudharabah).

Pada produk penghimpunan dana bank syariah dikenal dengan istilah simpanan terdiri dari giro, tabungan, dan deposito. Bank syariah umumnya menggunakan produk giro wadiah, tabungan dan deposito mudharabah.

Dalam penghimpunan dana bank syariah terdapat dua prinsip, yaitu prinsip wadi'ah dan prinsip mudharabah. Dalam hal kewenangan yang diberikan oleh pihak deposan atau pemilik dana yang menginvestasikan dananya di bank syariah, prinsip mudharabah terbagi dua yaitu: mudharabah mutlaqoh dan mudharabah muqoyyadah.

Beberapa faktor yang mempengaruhi bagi hasil yaitu persentase dana, total dana yang diterima, nisbah, metode penentuan bagi hasil, dan kebijakan akuntansi yang diterapkan. 
Tahapan yang dilakukan dalam menghitung bagi hasil penghimpunan dana di bank syariah antara lain menggunakan metode revenue sharing, memisahkan dana yang bersumber investasi mudharabah, menghitung seluruh total dana, menghitung rata-rata pembiayaan, menjumlahkan total pendapatan yang didapatkan, mengurangkan persentase investasi, dan menetapkan besarnya pendapatan yang diperoleh.

Metode yang dipakai dalam menghitung bagi hasil untuk penyimpan dana di bank syariah yaitu menghitung saldo rata-rata harian nasabah, menggunakan perhitungan hasil investasi per seribu dan menggunakan perhitungan bagi hasil berdasarkan saldo rata-rata harian seluruh simpanan dan pendapatan distribusi sejenis. 


\section{DAFTAR PUSTAKA}

Adiwarman A. Karim, Bank Islam: Analisis Fiqih dan Keuangan Jakarta: PT Raja Grafindo Persada, 2004.

Ansori, Abdul Ghofur, Penerapan Prinsip Syariah Dalam Lembaga Keuangan Lembaga Keuangan dan Perusahaan Pembiayaan Yogyakarta: Pustaka Pelajar, 2008

2008

Tanya Jawab Perbankan Syariah, Yogyakarta: UII Press,

Ari Kristin Prasetyoningrum, Risiko Bank Syariah, Yogyakarta: Pustaka Pelajar Bekerjasama dengan LP2M UIN Walisongo, 2015

Habib Nazhir dan Muhammad Hasanuddin, Ensiklopedi Ekonomi dan Perbankan Syariah Bandung: Kafa Publishing, 2008

Ismail, Perbankan Syariah. Jakarta: Kencana Prenada Media Group, 2011.

Kasmir, Dasar-Dasar Perbankan-Edisi Revisi 2014, Jakarta: Rajawali Pers, 2015

M.Sulhan \& Ely Siswanto, Manajemen Bank:Konvensional dan Syariah. Malang:

UIN-Malang Press, 2008

Muhamad, Sistem Bagi Hasil dan Pricing Bank Syariah, Yogyakarta: UII Press, 2016

Saeed, Abdulah. Menyoal Bank Syariah: Kritik atas Interpretasi Bunga Bank Kaum Neo-Revivalis. Jakarta: Paramadina, 2004

Wiroso, Penghimpunan Dana dan Distribusi Hasil Usaha Bank Syariah. Grasindo, Jakarta: 2005

Yunaldi, Wendra, Potret Perbankan Syariah di Indonesia, Jakarta Centralis, 2007 Internet:

https:/ / ojk.go.id, Otoritas Jasa Keuangan (OJK), Statistik Perbankan Syariah https://accounting.binus.ac.id https://www.syariahbukopin.co.id 